\title{
Determination of Lipophilic Marine Biotoxins in Mussels Harvested from the Adriatic Sea by LC-MS/MS
}

\author{
Maria Schirone ${ }^{1 * t}$, Miriam Berti ${ }^{2 \dagger}$, Pierina Visciano ${ }^{1}$, Francesco Chiumiento ${ }^{3}$, \\ Giacomo Migliorati ${ }^{3}$, Rosanna Tofalo ${ }^{1}$, Giovanna Suzzi ${ }^{1}$, Federica Di Giacinto ${ }^{2}$ and \\ Nicola Ferri ${ }^{2}$ \\ ${ }^{1}$ Faculty of Bioscience and Technology for Food, Agriculture and Environment, University of Teramo, Teramo, Italy, ${ }^{2}$ Biologia \\ delle Acque Interne, Istituto Zooprofilattico Sperimentale dell'Abruzzo e del Molise "G. Caporale", Teramo, Italy, \\ ${ }^{3}$ Bromatologia e Residui negli Alimenti per l'Uomo e gli Animali, Istituto Zooprofilattico Sperimentale dell'Abruzzo e del Molise \\ "G. Caporale", Teramo, Italy
}

OPEN ACCESS

Edited by:

Rosalba Lanciotti,

Università di Bologna, Italy

Reviewed by:

Fatih Ozogul,

Çukurova University, Turkey

Jorge Reinheimer,

National University of the Littoral,

Argentina

${ }^{*}$ Correspondence:

Maria Schirone

mschirone@unite.it

${ }^{\dagger}$ These authors have contributed equally to this work.

Specialty section: This article was submitted to

Food Microbiology,

a section of the journal

Frontiers in Microbiology

Received: 13 December 2017

Accepted: 23 January 2018

Published: 12 February 2018

Citation:

Schirone $M$, Berti M, Visciano $P$. Chiumiento F, Migliorati G, Tofalo $R$, Suzzi G, Di Giacinto F and Ferri N (2018) Determination of Lipophilic

Marine Biotoxins in Mussels

Harvested from the Adriatic Sea by LC-MS/MS. Front. Microbiol. 9:152.

doi: 10.3389/fmich.2018.00152
Lipophilic marine biotoxins include okadaic acid, pectenotoxin, yessotoxin and azaspiracid groups. The consumption of contaminated molluscs can lead to acute food poisoning syndromes depending on the exposure level. Regulatory limits have been set by Regulation (European Community, 2004a) No 853/2004 and LC-MS/MS is used as the official analytical method according to Regulation (European Community, 2011) No 15/2011. In this study specimens of mussels (Mytilus galloprovincialis) were collected along the coasts of the central Adriatic Sea during the years 2015-2017 and analyzed by the European harmonized Standard Operating Procedure. The method was validated for linearity, specificity, repeatability and reproducibility and it revealed able to be used for the detection of the lipophilic marine biotoxins. Levels of okadaic acid, pectenotoxin, yessotoxin and its analogs were detected at different concentrations in 148 (37\%) out of a total of 400 samples, always below the maximum limits, except for 11 (4.3\%) of them that were non-compliant because they exceeded the regulatory limit. Moreover, some samples were exposed to a multi-toxin mixture with regards to okadaic acid, yessotoxin and 1-Homo yessotoxin. Following these results, the aquaculture farms from which the non-compliant samples derived were closed until the analytical data of two consecutive samplings returned favorable. Besides the potential risk of consumption of mussels contaminated by lipophilic marine biotoxins, these marine organisms can be considered as bio-indicators of the contamination status of the marine ecosystem.

Keywords: marine biotoxins, okadaic acid, dinophysistoxin, azaspiracid, yessotoxin, Mytilus galloprovincialis, LC-MS/MS

\section{INTRODUCTION}

Lipophilic marine biotoxins (LMB) are toxic metabolites produced by some species of unicellular algae developing during natural phenomena known as harmful algal blooms. They are grouped in different classes, i.e., okadaic acid (OA), azaspiracids (AZA), yessotoxins (YTX), pectenotoxins (PTX), and spirolides (Ferron et al., 2016).

The OA group consists of OA and its isomers, the dinophysistoxins1 and 2 (DTX1, DTX2) and in addition the fatty acid ester derivatives of OA or DTX1 and DTX2 named DTX3 (Braga et al., 2017). These marine biotoxins are responsible of the human diarrhetic shellfish poisoning (DSP) characterized by gastrointestinal disorders such as nausea, vomiting, severe diarrhea and abdominal 
cramps (García et al., 2016). The mechanism of action of OA and DTX is linked to the inhibition of serine/threonine protein phosphatases (Ferreiro et al., 2015).

Besides gastrointestinal symptoms, AZA can be carcinogenic in mice and teratogenic to the developing fish (Twiner et al., 2012). Moreover, azaspiracid1 (AZA1) was demonstrated to be toxic to some human cell lines (B lymphocyte, monocyte, lung epithelial, T lymphocyte); azaspiracid2 (AZA2) has been shown to have a similar cytotoxicity with cytoskeleton alterations (Kim et al., 2017). Ferreiro et al. (2014a,b) reported that AZA2 could have acute arrhythmogenic potential in vivo and chronic effects on a specific cardiac potassium channel in vitro. Also YTX and its analogs can present cardiotoxicity with mitochondrial damage in cardiomyocytes after repeated exposure and marked bradycardia and hypotension in rats (Ferreiro et al., 2016), while some PTX are hepatotoxic to mice by intraperitoneal injection (Trainer et al., 2013). The European Legislation set maximum levels in Regulations (European Community, 2004a) No 853/2004 and (European Community, 2013) No 786/2013, corresponding to $160 \mu \mathrm{g}$ of OA equivalent $\mathrm{kg}^{-1}$ for OA, DTX and PTX together, $160 \mu \mathrm{g}$ of AZA equivalent $\mathrm{kg}^{-1}$ for AZA and $3.75 \mathrm{mg}$ YTX equivalent $\mathrm{kg}^{-1}$ for YTX-group.

The Regulation (European Community, 2005) No 2074/2005 established the official analytical methods to be used for the detection of LMB, which were represented by the mouse bioassay (MBA) and the rat bioassay (RBA). However, these methods showed some disadvantages other than ethical, such as the high variability in results, the insufficient detection capability and the limited specificity. Therefore, developed alternatives to the biological methods were successfully tested and a liquid chromatography-mass spectrometry (LC-MS/MS) method was validated and recognized as the official method by the Regulation (European Community, 2011) No 15/2011 since 31 December 2014. The aim of this study was the application of the EU Harmonised Standard Operating Procedure for determination of Lipophilic marine biotoxins in molluscs by LC-MS/MS (2015) in specimens of Mytilus galloprovincialis coming from different aquaculture farms located along the central Adriatic coasts. The samples were collected according to the multi-annual regional control plan 2015-2018, which requires the samplings twice a month. Another objective of this study was the validation of the method for the criteria established by Regulation (European Community, 2004c) No 882/2004.

\section{MATERIALS AND METHODS Collection of Specimens and Sample Preparation}

Specimens of M. galloprovincialis were collected from 12 aquaculture farms located along the coasts of Abruzzo and Molise regions, in coastal areas belonging to the following 4 provinces: Teramo, Pescara, Chieti (Abruzzo) and Campobasso (Molise).

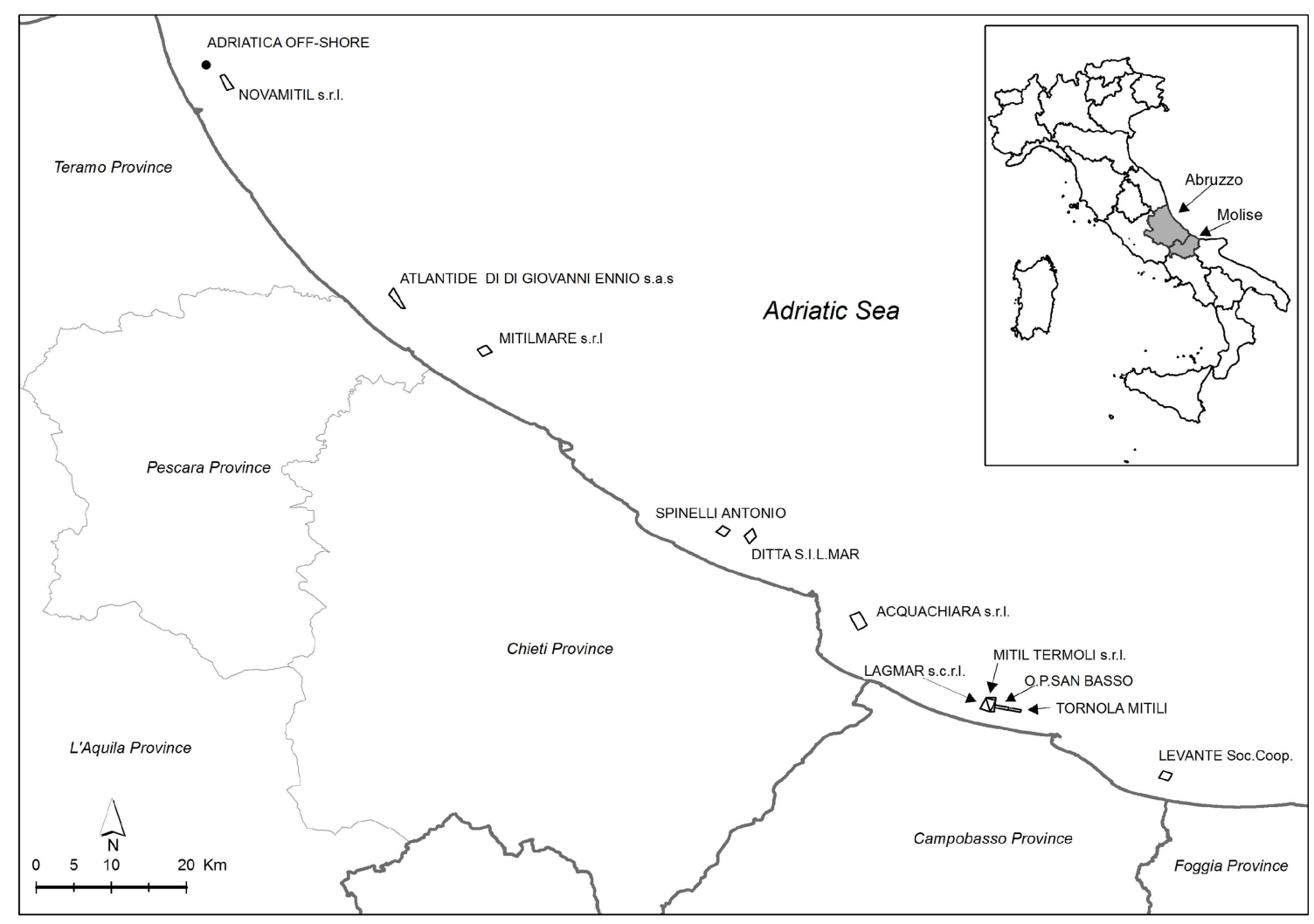

FIGURE 1 | Map of the sampling sites along the coasts of the central Adriatic Sea. 
TABLE 1 | Longitude and latitude of the sampling points.

\begin{tabular}{lllcc}
\hline Region & Aquaculture Farm & Points & Longitude (East) & Latitude (Nord) \\
\hline Abruzzo & Adriatica Off-Shore & A & 13,985277 & 42,808611 \\
& Novamitil S.R.L. & A-D & $14,001666 / 14,006667 / 14,018334 / 14,009999$ & $42,794999 / 42,797499 / 42,780833 / 42,778331$ \\
& Atlantide Di Giovanni & A-D & $14,204166 / 14,209722 / 14,223611 / 14,218055$ & $42,533333 / 42,541666 / 42,516666 / 42,518055$ \\
& Mitilmare S.R.L. & A-D & $14,310097 / 14,321057 / 14,327828 / 14,316638$ & $42,467663 / 42,472476 / 42,464385 / 42,459421$ \\
& Spinelli Antonio & A-D & $14,596670 / 14,604170 / 14,613330 / 14,606670$ & $42,248670 / 42,256170 / 42,251000 / 42,243500$ \\
& Ditta S.I.L. Mar & A-D & $14,630555 / 14,640277 / 14,644444 / 14,636111$ & $42,244444 / 42,252777 / 42,243055 / 42,234722$ \\
Moquachiara S.R.L. & A-D & $14,756833 / 14,768333 / 14,777130 / 14,766667$ & $42,148167 / 42,152667 / 42,137642 / 42,131167$ \\
& Lagmar S.C.R.L. & A-D & $14,920000 / 14,931667 / 14,925000 / 14,913333$ & $42,050000 / 42,046670 / 42,033330 / 42,036670$ \\
& Mitil Termoli S.R.L. & A-D & $14,920000 / 14,931944 / 14,930000 / 14,925000$ & $42,050000 / 42,050000 / 42,033330 / 42,033330$ \\
& O.P. San Basso & A-D & $14,931110 / 14,947500 / 14,946944 / 14,930000$ & $42,041390 / 42,038610 / 42,035000 / 42,038060$ \\
& Tornola Mitili & A-D & $14,949157 / 14,962088 / 14,961113 / 14,948183$ & $42,037970 / 42,035570 / 42,032620 / 42,034900$ \\
& Levante Soc. Coop. & A-D & $15,132375 / 15,143406 / 15,138489 / 15,127458$ & $41,962340 / 41,958650 / 41,950450 / 41,954140$ \\
\hline
\end{tabular}

TABLE 2 | LC-MS/MS parameters for detection of marine biotoxins in MRM mode.

\begin{tabular}{|c|c|c|c|c|c|c|c|}
\hline Biotoxin & ESI & $\begin{array}{l}\text { Precursor ion } \Rightarrow \\
\text { product ion }(m / z)\end{array}$ & $\mathrm{DP}^{\mathrm{a}}$ & FP $^{b}$ & $E P^{c}$ & $C E^{d}$ & $\mathrm{CXP}^{\mathrm{e}}$ \\
\hline OA & $N^{1}$ & $\begin{array}{l}803.6 \Rightarrow 255.3 \\
803.6 \Rightarrow 113.3\end{array}$ & -146 & -350 & -10 & $\begin{array}{l}-65 \\
-78\end{array}$ & -4 \\
\hline DTX1 & $\mathrm{N}$ & $\begin{array}{l}817.6 \Rightarrow 255.5 \\
817.6 \Rightarrow 112.8\end{array}$ & -130 & -340 & -13 & $\begin{array}{l}-90 \\
-70\end{array}$ & -10 \\
\hline DTX2 & $\mathrm{N}$ & $\begin{array}{l}803.6 \Rightarrow 255.3 \\
803.6 \Rightarrow 113.3\end{array}$ & -80 & -315 & -13 & $\begin{array}{l}-65 \\
-88\end{array}$ & $\begin{array}{l}-1 \\
-6\end{array}$ \\
\hline YTX & $\mathrm{N}$ & $\begin{array}{c}1,141.6 \Rightarrow 1,061.7 \\
1,141.6 \Rightarrow 855.6\end{array}$ & -110 & -350 & -14 & $\begin{array}{l}-45 \\
-96\end{array}$ & $\begin{array}{l}-16 \\
-10\end{array}$ \\
\hline 1-Homo YTX & $\mathrm{N}$ & $\begin{array}{c}1,155.6 \Rightarrow 1,075.6 \\
1,155.6 \Rightarrow 869.6\end{array}$ & -100 & -350 & -14 & $\begin{array}{l}-46 \\
-100\end{array}$ & $\begin{array}{l}-18 \\
-10\end{array}$ \\
\hline 45 OH YTX & $\mathrm{N}$ & $\begin{array}{c}1,157.5 \Rightarrow 1,077.7 \\
1,157.5 \Rightarrow 871.5\end{array}$ & -110 & -350 & -14 & $\begin{array}{l}-45 \\
-96\end{array}$ & $\begin{array}{l}-16 \\
-10\end{array}$ \\
\hline $\begin{array}{l}45 \mathrm{OH}-\text { Homo } \\
\text { YTX }\end{array}$ & $\mathrm{N}$ & $\begin{array}{c}1,171.5 \Rightarrow 1,091.5 \\
1,171.5 \Rightarrow 869.9\end{array}$ & -100 & -350 & -14 & $\begin{array}{l}-46 \\
-100\end{array}$ & $\begin{array}{l}-18 \\
-10\end{array}$ \\
\hline AZA1 & $P^{2}$ & $\begin{array}{l}842.4 \Rightarrow 824.4 \\
842.6 \Rightarrow 806.7\end{array}$ & 85 & 385 & 10 & $\begin{array}{l}40 \\
55\end{array}$ & $\begin{array}{l}10 \\
11\end{array}$ \\
\hline AZA2 & $\mathrm{P}$ & $\begin{array}{l}856.6 \Rightarrow 838.5 \\
856.6 \Rightarrow 820.6\end{array}$ & 81 & 360 & 10 & $\begin{array}{l}43 \\
53\end{array}$ & 12 \\
\hline AZA3 & $\mathrm{P}$ & $\begin{array}{l}828.6 \Rightarrow 810.6 \\
828.6 \Rightarrow 792.4\end{array}$ & 72 & 360 & 8 & $\begin{array}{l}43 \\
53\end{array}$ & $\begin{array}{l}18 \\
11\end{array}$ \\
\hline PTX2 & $\mathrm{P}$ & $\begin{array}{l}876.6 \Rightarrow 823.5 \\
876.6 \Rightarrow 212.9\end{array}$ & 74 & 375 & 9 & $\begin{array}{l}33 \\
36\end{array}$ & 11 \\
\hline PTX1 & $\mathrm{P}$ & $\begin{array}{l}892.5 \Rightarrow 821.5 \\
892.5 \Rightarrow 213.2\end{array}$ & 74 & 375 & 9 & $\begin{array}{l}33 \\
36\end{array}$ & 11 \\
\hline
\end{tabular}

${ }^{1} N$, Negative; ${ }^{2}$ P, Positive; a DP, Declustering Potential; ${ }^{b} F P$, Focusing Potential; ${ }^{c} E P$, Entrance Potential; ${ }^{d} \mathrm{CE}$, Collision Energy; ${ }^{e} \mathrm{CXP}$, Collision Cell Exit Potential.

The samples were taken from 4 different sampling points (from A to D), except for a farm in which just only one sampling point was considered (Figure 1). In Table 1, longitude and latitude for each sampling point were reported.

The sampling was made according to the multi-annual regional control plan 2015-2018. The frequency for the determination of marine biotoxins was established twice in a month or more frequently when the contamination in mussels increased.

A total of 400 global samples, each formed by 150 specimens of M. galloprovincialis, were collected during the investigated years, and more in detail 126 samples in 2015, 173 samples in 2016, and 101 samples from January to July 2017.
The mussels were opened, removed from the shell, washed with running water to remove any residues and pooled according to their origin, to form the global samples. Then, each global sample was homogenized with a blender and stored at $-20^{\circ} \mathrm{C}$ until the analysis. The extraction procedure was carried out for $2 \mathrm{~g}$ of the homogenate.

\section{Chemicals and Standards Preparation}

All chemicals were of analytical reagent grade: methanol (LC-MS grade), acetonitrile (LC-MS grade) and ammonium formate (99\% purity), formic acid (98\%), hydrochloric acid (37\%), and sodium hydroxide (99\%) and were purchased from Sigma-Aldrich (St. Louis, MO, USA). Water was prepared with high-purity water obtained from a Milli-Q ${ }^{\circledR}$ system (Merck Millipore, Darmstadt, Germany).

The certified reference standard solutions of OA (CRM-OAc), DTX1 (CRM-DTX1) and DTX2 (CRM-DTX2), PTX2 (CRMPTX2), AZA1 (CRM-AZA1), AZA2 (CRM-AZA2), AZA3 (CRM-AZA3), YTX (CRM-YTX), 1-Homo YTX (CRM-Homo YTX), certified reference material with OA, and DTX (CRMDSP-MUS-b), homogenate of digestive gland of mussel (Mytilus edulis) with OA and DTX were all purchased from the Certified Reference Materials Program of the Institute for Marine Biosciences, National Research Council Canada (Ottawa, Ontario, Canada). The calibration curve for all biotoxins was prepared in methanol following the EU-harmonized SOP.

\section{Instrumental Analysis}

The instrumental analysis was performed by a Perkin Elmer HPLC system (Perkin Elmer, Waltham, MA, USA) constituted of a model 200 microbinary pump and a model 200 auto-sampler. A reversed-phase HPLC column X-Bridge C18 $(50 \times 2.1 \mathrm{~mm}$, $2.5 \mu \mathrm{m})$ with relative guard column X-Bridge C18 $(10 \times 2.1 \mathrm{~mm}$, $2.5 \mu \mathrm{m}$ ) both from Waters (Milford, MA, USA) were used. The flow rate was set to $0.3 \mathrm{ml} \mathrm{min} \mathrm{m}^{-1}$ and the injection volume was 20 $\mu \mathrm{l}$. The mobile phase was used in gradient mode as follows: $90 \%$ of eluent A (100\% water containing $2 \mathrm{mM}$ ammonium formate and $50 \mathrm{mM}$ formic acid) and $10 \%$ of eluent B (95\% acetonitrile: $5 \%$ water containing $2 \mathrm{mM}$ ammonium formate and $50 \mathrm{mM}$ 
TABLE 3 | Simultaneous presence of okadaic acid (OA), yessotoxin (YTX), and 1-Homo YTX in samples distinguished by provenance.

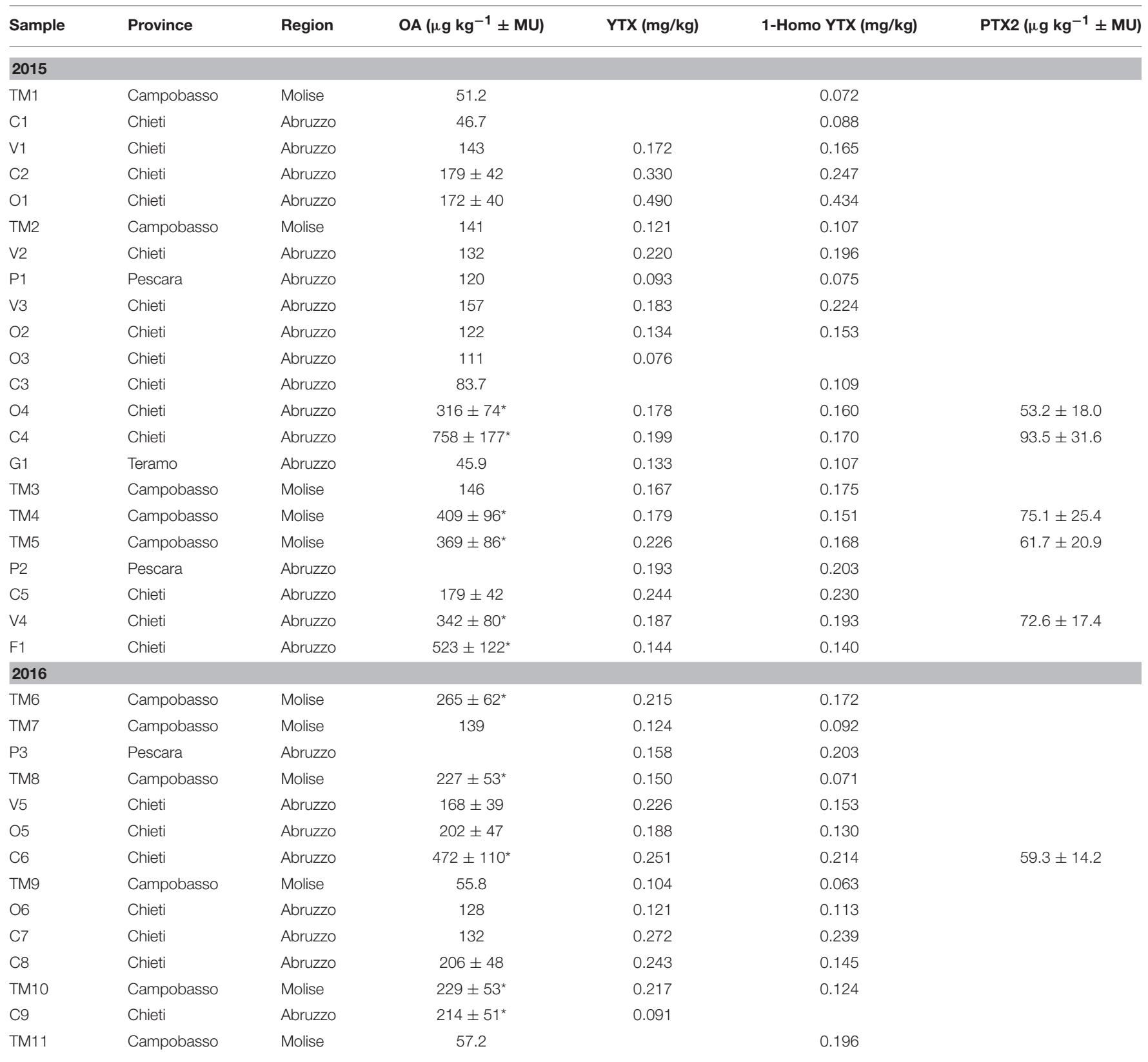

*Samples exceeding the maximum limit and non-compliant based on the Measurement Uncertainty (MU).

formic acid) at $0-10 \mathrm{~min}$, then eluent $\mathrm{B}$ increased up to $90 \%$ at time $10-13 \mathrm{~min}$ and decreased again to $10 \%$ at $13-16 \mathrm{~min}$ up to $20 \mathrm{~min}$.

The LC-MS/MS analysis was carried out by a mass spectrometer API 3000 PE SCIEX (Applied Biosystems, Toronto, ON, Canada) equipped with an electrospray interface set in the positive ionization mode (ESI+) for PTX and AZA-groups, and the negative ionization mode (ESI-) for OA, DTX- and YTXgroups. The mass spectrometer was set in multiple reaction monitoring (MRM) mode, with specific transition parameters as reported in Table 2. The capillary voltage was set at $5.5 \mathrm{kV}$ for $\mathrm{ESI}+,-4.5 \mathrm{kV}$ for $\mathrm{ESI}-$, and the ion source temperature at $550^{\circ} \mathrm{C}$.

\section{RESULTS AND DISCUSSION Concentrations of Lipophilic Marine Biotoxins}

In this study, the monitoring for LMB occurrence in specimens of M. galloprovincialis collected during the years 2015-2017 showed a good trend with regards to the compliance with the regulatory limits. To express the results by each toxin group according 
TABLE 4 | Concentration of okadaic acid $(O A)$ in samples distinguished by provenance.

\begin{tabular}{|c|c|c|c|}
\hline Sample & Province & Region & $\mathrm{OA}\left(\mu \mathrm{g} \mathrm{kg}^{-1} \pm \mathrm{MU}\right)$ \\
\hline \multicolumn{4}{|l|}{2015} \\
\hline $\mathrm{O} 7$ & Chieti & Abruzzo & 57.4 \\
\hline T1 & Teramo & Abruzzo & 95.9 \\
\hline TM12 & Campobasso & Molise & 86.7 \\
\hline V6 & Chieti & Abruzzo & $202 \pm 47$ \\
\hline \multicolumn{4}{|l|}{2016} \\
\hline TM13 & Campobasso & Molise & 84.2 \\
\hline TM14 & Campobasso & Molise & 91.3 \\
\hline TM15 & Campobasso & Molise & 118 \\
\hline TM16 & Campobasso & Molise & 72.5 \\
\hline TM17 & Campobasso & Molise & 103 \\
\hline C10 & Chieti & Abruzzo & 114 \\
\hline TM18 & Campobasso & Molise & 42.5 \\
\hline TM19 & Campobasso & Molise & 44.6 \\
\hline О8 & Chieti & Abruzzo & 65.6 \\
\hline O9 & Chieti & Abruzzo & 55.1 \\
\hline C11 & Chieti & Abruzzo & 45.3 \\
\hline 010 & Chieti & Abruzzo & 60.0 \\
\hline TM20 & Campobasso & Molise & 57.2 \\
\hline
\end{tabular}

to the European legislation (i.e., as $\mu$ g equivalents $\mathrm{kg}^{-1}$ or $\mathrm{mg}$ equivalents $\mathrm{kg}^{-1}$ ) the use of the Toxicity Equivalent Factors (TEFs) was required. Therefore, the individual content of each detected biotoxin/analog was multiplied with the corresponding TEF before summarizing the total equivalents for the respective group toxins (European Food Safety Authority, 2009).

Among the investigated $\mathrm{LMB}$, concentrations above the LOQ were found only for OA, PTX, YTX, and its analogs. Moreover, mussels were often exposed to a multi-toxin mixture because some samples contained more than one LMB. The simultaneous presence of OA, YTX, and 1-Homo YTX were detected in 17 and 11 samples collected in 2015 and 2016 years, respectively. Moreover, 6 out of these 28 samples had also PTX2 concentrations. A total of 11 samples exceeded the regulatory maximum limit of $160 \mu \mathrm{g}$ of OA equivalents $\mathrm{kg}^{-1}$ (Table 3). The samples showing only OA levels ranging from 42.5 to $114 \mu \mathrm{g}$ of OA equivalents $\mathrm{kg}^{-1}$ were reported in Table 4. The sample named V6, collected from Chieti province, had a value of $202 \pm$ $47 \mu \mathrm{g}$ of $\mathrm{OA}$ equivalents $\mathrm{kg}^{-1}$, but it was considered compliant based on the measurement uncertainty. Table 5 showed samples containing only YTX and its analogs, even if none of them exceeded the maximum limit for this group. The remaining investigated LMB, i.e., AZA- and DTX-groups, and $45 \mathrm{OH}-$ Homo YTX, were never detected.

The occurrence of marine harmful algae is increasing worldwide and therefore, the accumulation of LMB from harmful phytoplankton represents a food safety threat in the shellfish industry. In the present study, LMB belonging to the OA-group were the only compounds exceeding the regulatory limits of $160 \mu \mathrm{g}$ of OA equivalent $\mathrm{kg}^{-1}$. In particular, the samples coming from Chieti and Campobasso provinces resulted non-compliant and therefore their production areas were closed according the multi-annual regional control plan 2015-2018 for Abruzzo ${ }^{1}$ and Molise regions. Moreover, this plan established that in case of non-compliant samples, the rapid alert system should be activated and harvesting molluscs from the contaminated areas should be suspended until the results of two consecutive samplings are compliant. In addition, Regulation (European Community, 2004b) No 854/2004 affirms that in such circumstance the production area of bivalve molluscs should be closed by the competent authority and it could be re-opened when at least two consecutive results of biotoxin levels meet with the legislative criteria.

Also other authors reported frequent closures of bivalve fisheries of the west coast of Ireland due to AZA presence in the blue edible mussel M. edulis (Murray et al., 2017).

Our previous studies carried out in mussels coming from the central Adriatic Sea showed a similar trend with regards to YTX content, while no presence of the other investigated LMB was observed. The monitoring plans for the determination of LMB and domoic acid (DA) in samples of M. galloprovincialis during the years 2006-2009 revealed no presence of these compounds, neither by MBA used for LMB, nor by a chromatographic analysis for DA detection (Schirone et al., 2011). These results demonstrated a good condition of the monitored marine zones for the occurrence of marine biotoxins, even if a high intensity of algal blooms in Adriatic Sea have been frequently reported in the last years. However, the DSP outbreak occurrence remains still very difficult to predict due to the high variability of biotoxin content in phytoplankton cells (Leonardo et al., 2017). In another study (Schirone et al., 2013), YTX levels were found in M. galloprovincialis specimens taken from three Italian regions (i.e., Abruzzo, Molise, Emilia Romagna) along the coasts of the Adriatic Sea, at concentrations ranging from 0.2 to $1.8 \mathrm{mg}$ of YTX equivalent $\mathrm{kg}^{-1}$. Some samples coming from Emilia Romagna region exceeded the maximum limit ( $1 \mathrm{mg}$ of YTX equivalent $\mathrm{kg}^{-1}$ ) that was in force in the period of the investigation, instead of the new limit of $3.75 \mathrm{mg}$ of YTX equivalent $\mathrm{kg}^{-1}$ fixed by Regulation (European Community, 2013) No 786/2013. These analyses were carried out by a functional method as alternative to MBA for the in vitro quantitative detection of YTX. The positive samples were also confirmed by MBA causing the death of two out three mice within $24 \mathrm{~h}$ of inoculation with the extract of the mollusc, even if this method showed low specificity and sensitivity because it did not provide the identification and quantification of the biotoxin causing the death of mice. A comparison among the two cited assays and a LCMS/MS method was studied by analyzing other samples of $M$. galloprovincialis collected from the Adriatic Sea (Visciano et al., 2013). The results showed the presence of YTX at concentrations up to 1.63 and $1.97 \mathrm{mg}$ of YTX equivalent $\mathrm{kg}^{-1}$ by the functional assay and LC-MS/MS, respectively. Moreover, the last method allowed the detection also of YTX analogs, i.e., homo YTX and carboxy homo YTX. The authors supposed that the influx of

\footnotetext{
${ }_{1}^{1}$ Piano Pluriennale Regionale Integrato dei Controlli della Sanità Pubblica veterinaria e Sicurezza Alimentare della Regione Abruzzo 2015-2018. $3^{\text {rd }}$ Edn. $1-892$.
} 
TABLE 5 | Concentrations ( $\mathrm{mg} / \mathrm{kg}$ ) of yessotoxin (YTX) and its analogs distinguished for provenance.

\begin{tabular}{|c|c|c|c|c|c|}
\hline $\begin{array}{l}\mathbf{N}^{\circ} \text { of } \\
\text { samples }\end{array}$ & Province & Region & YTX & 45 OH-YTX & 1-Homo YTX \\
\hline \multicolumn{6}{|l|}{2015} \\
\hline 16 & Chieti & Abruzzo & $\begin{array}{l}0.067 \text { (V7), } 0.088 \text { (V8), } 0.099 \text { (F2), } 0.110 \text { (V9), } \\
0.084 \text { (F3), } 0.132 \text { (C13), } 0.210 \text { (V11), } 0.092 \\
\text { (F4), } 0.121 \text { (O11), 0.183 (V12), 0.172 (O12), } \\
0.165 \text { (C14), } 0.126 \text { (FS1), 1.080 (O13) }\end{array}$ & 0.074 (V8), 0.082 (F2), 0.091 (V9) & $\begin{array}{l}0.091 \text { (V8), } 0.106 \text { (F2), } 0.100 \text { (C12), } 0.143 \text { (V9), } \\
0.112 \text { (V10), } 0.124 \text { (C13), } 0.173 \text { (V11), } 0.077 \\
\text { (F4), } 0.118 \text { (O11), } 0.154 \text { (V12), } 0.160 \text { (O12), } \\
0.104 \text { (C14), } 0.084 \text { (FS1), } 1.02 \text { (O13) }\end{array}$ \\
\hline 14 & Campobasso & Molise & $\begin{array}{l}0.103 \text { (TM22), } 0.093 \text { (TM23), } 0.101 \text { (TM25), } \\
0.092 \text { (TM26), } 0.200 \text { (TM27), } 0.087 \text { (TM28), } \\
0.136 \text { (TM29), } 0.176 \text { (TM30), } 0.111 \text { (TM31), } \\
0.118 \text { (TM32), } 0.105 \text { (TM33) }\end{array}$ & 0.091 (TM23) & $\begin{array}{l}0.110 \text { (TM21), } 0.131 \text { (TM22), } 0.076 \text { (CB1), } \\
0.116 \text { (TM24), } 0.095 \text { (TM25), } 0.145 \text { (TM27), } \\
0.093 \text { (TM28), } 0.115 \text { (TM29), } 0.107 \text { (TM30), } \\
0.062 \text { (TM31), } 0.089 \text { (TM32), } 0.072 \text { (TM33) }\end{array}$ \\
\hline 1 & Pescara & Abruzzo & 0.073 (P12) & & 0.072 (P12) \\
\hline 2 & Chieti & Abruzzo & 0.109 (C15), 0.094 (V13) & & \\
\hline 2 & Campobasso & Molise & 0.107 (TM34), 0.105 (TM35) & & \\
\hline \multicolumn{6}{|l|}{2017} \\
\hline 6 & Teramo & Abruzzo & $\begin{array}{l}0.133 \text { (T4), } 0.108 \text { (T5), } 0.090 \text { (T6), } 0.167 \text { (T7), } \\
0.186 \text { (T8), } 0.232 \text { (T9) }\end{array}$ & & \\
\hline 17 & Chieti & Abruzzo & $\begin{array}{l}0.229 \text { (O14), } 0.397 \text { (V14), } 0.286 \text { (O15), } 0.156 \\
\text { (V15), } 0.257 \text { (C16), 0.245 (C17), 0.167 (C18), } \\
0.137 \text { (N16), } 0.522 \text { (C19), } 0.215 \text { (C20), } 0.145 \\
\text { (O16), } 0.282 \text { (O17), } 0.153 \text { (C21), } 0.184 \text { (V17), } \\
0.125 \text { (O18), } 0.162 \text { (C22), } 0.173 \text { (C23) }\end{array}$ & & \\
\hline
\end{tabular}

TABLE 6 | Correlation coefficient for the investigated lipophilic marine biotoxins.

\begin{tabular}{ll}
\hline Biotoxin & $\boldsymbol{R}^{\mathbf{2}}$ \\
\hline OA & 0.9993 \\
DTX1 & 0.9991 \\
DTX2 & 0.9944 \\
PTX2 & 0.9996 \\
AZA1 & 0.9998 \\
AZA2 & 0.9990 \\
AZA3 & 0.9998 \\
YTX & 0.9992 \\
1-Homo YTX & 0.9997 \\
\hline
\end{tabular}

the waters from the Po, the most important river of Italy, on phytoplankton bloom dynamics, as well as the clear seasonal variability in the circulation and ecosystem of the Adriatic Sea due to strong forcing functions could affect the presence of this compound.

In the present study the concentrations of YTX and its analogs were lower than the above reported values (Schirone et al., 2013; Visciano et al., 2013) while levels of LMB belonging to OA-group were detected for the first time. These results confirmed that $\mathrm{OA}$ is gaining a high critical interest because it represents the most predominant DSP biotoxin in the European coasts (González-Romero et al., 2012). Bacchiocchi et al. (2015) found concentrations ranging between 5 and $25 \mu \mathrm{g}$ of OA equivalent $\mathrm{kg}^{-1}$ in samples of $M$. galloprovincialis collected along the coast of Marche region, Adriatic Sea (Italy) during the years 2012-2013, whereas DTX were never detected. Levels of YTX and its analogs were also reported, reaching values near or slightly above the regulatory limit. However, Pistocchi et al. (2012) described that the Northern Adriatic Sea has been characterized by the presence of toxic algae producing $\mathrm{OA}$ and DTX until 1997 and YTX in the past decades. Moreover, Orellana et al. (2017) found similar results to those obtained in the present study, showing that OA/DTX2 and YTX were the most abundantly accumulated LMB in the analyzed mussels (M. edulis, Crassostrea gigas and Patella sp.) coming from the Belgian Part of the North Sea and reaching values of 25.4 and $169.2 \mu \mathrm{g}$ equivalent $\mathrm{kg}^{-1}$ wet, respectively. Gerssen et al. (2010) found concentrations ranging from 18.2 to $67.5 \mu \mathrm{g}$ of OA equivalent $\mathrm{kg}^{-1}$ in mussels (M. edulis) collected from the Dutch shellfish harvesting areas. 
TABLE 7 | Levels of validation for the determination of Toxicity Equivalent Quantitation for OA-group.

\begin{tabular}{|c|c|c|c|c|c|c|c|}
\hline Biotoxin & TEF & $\begin{array}{c}\text { Level } 1 \\
\left(\mu \mathrm{kg}^{-1}\right)(n=6)\end{array}$ & $\begin{array}{l}\text { TEQ level } 1 \\
\left(\mu \mathrm{g} \mathrm{kg}^{-1}\right)\end{array}$ & $\begin{array}{c}\text { Level } 2 \\
\left(\mu \mathrm{g} \mathrm{kg}^{-1}\right)(n=6)\end{array}$ & $\begin{array}{c}\text { TEQ level } 2 \\
\left(\mu \mathrm{g} \mathrm{kg}^{-1}\right)\end{array}$ & $\begin{array}{c}\text { Level } 3 \\
\left(\mu \mathrm{g} \mathrm{kg}^{-1}\right)(n=6)\end{array}$ & $\begin{array}{c}\text { TEQ level } 3 \\
\left(\mu \mathbf{~ k g}^{-1}\right)\end{array}$ \\
\hline OA & 1 & 45 & 45 & 67.5 & 67.5 & 90 & 90 \\
\hline DTX2 & 0.6 & 45 & 27 & 67.5 & 40.5 & 90 & 54 \\
\hline PTX2 & 1 & 45 & 45 & 67.5 & 67.5 & 90 & 90 \\
\hline \multicolumn{3}{|c|}{ Sum (as $\mu \mathrm{g}$ of $\mathrm{OA}$ equivalent $\mathrm{kg}^{-1}$ ) } & 162 & & 243 & & 324 \\
\hline
\end{tabular}

TABLE 8 | Levels of validation for the determination of Toxicity Equivalent Quantitation for AZA-group.

\begin{tabular}{|c|c|c|c|c|c|c|c|}
\hline Biotoxin & TEF & $\begin{array}{c}\text { Level 1 } \\
\left(\mu \mathrm{kg}^{-1}\right)(n=6)\end{array}$ & $\begin{array}{l}\text { TEQ level } 1 \\
\left(\mu \mathbf{g ~ k g}^{-1}\right)\end{array}$ & $\begin{array}{c}\text { Level } 2 \\
\left(\mu \mathrm{gg}^{-1}\right)(n=6)\end{array}$ & $\begin{array}{c}\text { TEQ level } 2 \\
\left(\mu \mathrm{g} \mathrm{kg}^{-1}\right)\end{array}$ & $\begin{array}{c}\text { Level } 3 \\
\left(\mu \mathrm{gg}^{-1}\right)(n=6)\end{array}$ & $\begin{array}{c}\text { TEQ level } 3 \\
\left(\mu \mathbf{~ k g}^{-1}\right)\end{array}$ \\
\hline AZA1 & 1 & 40 & 40 & 60 & 60 & 80 & 80 \\
\hline AZA3 & 1.4 & 40 & 56 & 60 & 84 & 80 & 112 \\
\hline \multicolumn{3}{|c|}{ Sum (as $\mu \mathrm{g}$ of AZA equivalent $\mathrm{kg}^{-1}$ ) } & 168 & & 252 & & 336 \\
\hline
\end{tabular}

TABLE 9 | Levels of validation for the determination of Toxicity Equivalent Quantitation for YTX group.

\begin{tabular}{|c|c|c|c|c|c|c|c|}
\hline Biotoxin & TEF & $\begin{array}{c}\text { Level 1 } \\
\left(\mathrm{mg} \mathrm{kg}^{-1}\right)(n=6)\end{array}$ & $\begin{array}{l}\text { TEQ level } 1 \\
\left(\mathrm{mg} \mathrm{kg}^{-1}\right)\end{array}$ & $\begin{array}{c}\text { Level } 2 \\
\left(\mathrm{mg} \mathrm{kg}^{-1}\right)(n=6)\end{array}$ & $\begin{array}{l}\text { TEQ level } 2 \\
\left(\mathrm{mg} \mathrm{kg}^{-1}\right)\end{array}$ & $\begin{array}{c}\text { Level } 3 \\
\left(\mathrm{mg} \mathrm{kg}^{-1}\right)(n=6)\end{array}$ & $\begin{array}{l}\text { TEQ level } 3 \\
\left(\mathrm{mg} \mathrm{kg}^{-1}\right)\end{array}$ \\
\hline YTX & 1 & 0.94 & 0.94 & 1.88 & 1.88 & 2.82 & 2.82 \\
\hline \multicolumn{3}{|c|}{ Sum (as mg of YTX equivalent $\mathrm{kg}^{-1}$ ) } & 1.88 & & 3.75 & & 5.64 \\
\hline
\end{tabular}

TABLE 10 | Repeatability data.

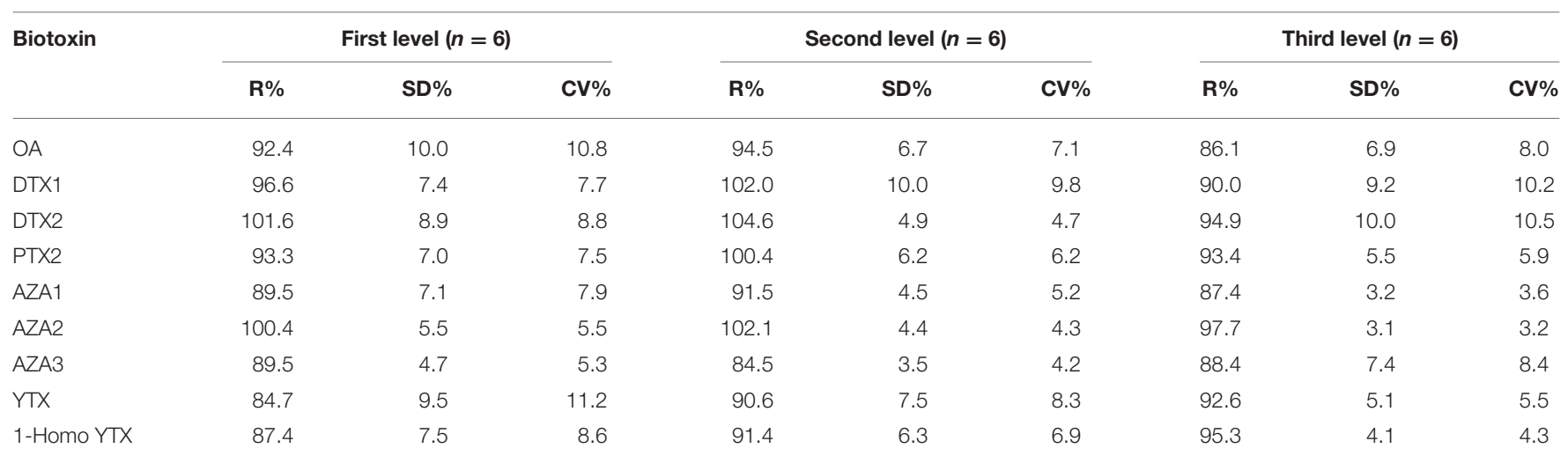

$R$, Recovery; SD, Standard Deviation; CV, Coefficient Variation.

Levels of $\mathrm{OA}$, ranging from 40 to $611 \mu \mathrm{g}$ of $\mathrm{OA}$ equivalent $\mathrm{kg}^{-1}$ were also detected by Garibo et al. (2014) in samples of $M$. galloprovincialis obtained from the shellfish monitoring program of the Catalan littoral (NW Mediterranean) during a DSP event in 2012. Also in that circumstance, the closure of the production area due to OA levels above the regulatory limit was observed. On the contrary, other studies (Blanco et al., 2017) reported AZA concentrations up to a maximum of $5.4 \mathrm{mg}$ of AZA1 equivalent $\mathrm{kg}^{-1}$ in mussels (M. galloprovincialis) collected during the official monitoring programs of production areas located along the Atlantic and Cantabrian coasts of Spain. The authors supposed that this contamination was linked to the downwelling or upwelling relaxation in the outer (more oceanic) part of the sampling zones, and the molluscs became affected when the plankton populations were advected to the shore.

\section{Validation Study}

The method was validated for the criteria established in Regulation (European Community, 2004c) No 882/2004. The linearity was tested by five points calibration curves in the range 1.5-50 $\mathrm{g} \mathrm{l}^{-1}$ for OA-group, 1.5-40 $\mu \mathrm{g} \mathrm{l}^{-1}$ for AZA- and PTXgroup, and 3.75-250 $\mu \mathrm{g}^{-1}$ for YTX-group. The correlation 
TABLE 11 | Reproducibility data.

\begin{tabular}{|c|c|c|c|c|c|c|c|c|c|}
\hline \multirow[t]{2}{*}{ Biotoxi n } & \multicolumn{3}{|c|}{ First level $(n=12)$} & \multicolumn{3}{|c|}{ Second level $(n=12)$} & \multicolumn{3}{|c|}{ Third level $(n=12)$} \\
\hline & $\mathbf{R} \%$ & SD\% & CV\% & $\mathbf{R} \%$ & SD \% & CV\% & $\mathbf{R} \%$ & SD\% & CV\% \\
\hline OA & 91.0 & 9.7 & 10.7 & 91.6 & 10.0 & 10.9 & 89.0 & 8.6 & 9.6 \\
\hline DTX1 & 96.3 & 7.1 & 7.4 & 102.8 & 8.1 & 7.8 & 96.2 & 10.1 & 10.5 \\
\hline DTX2 & 101.6 & 10.1 & 9.9 & 102.3 & 7.7 & 7.6 & 92.0 & 4.7 & 5.1 \\
\hline PTX2 & 93.7 & 5.6 & 6.0 & 96.5 & 6.9 & 7.2 & 93.4 & 5.5 & 5.9 \\
\hline AZA1 & 89.3 & 5.8 & 6.5 & 90.6 & 4.4 & 4.8 & 88.1 & 3.1 & 3.5 \\
\hline AZA2 & 100.0 & 6.6 & 6.6 & 103.7 & 4.6 & 4.4 & 101.3 & 5.8 & 5.7 \\
\hline AZA3 & 89.0 & 5.2 & 5.9 & 85.7 & 3.7 & 4.4 & 86.3 & 5.9 & 6.8 \\
\hline YTX & 89.7 & 9.3 & 10.4 & 91.4 & 6.3 & 6.9 & 90.7 & 5.0 & 5.5 \\
\hline 1-Homo YTX & 89.9 & 6.8 & 7.5 & 91.7 & 7.0 & 7.6 & 92.6 & 4.7 & 5.1 \\
\hline
\end{tabular}

R, Recovery; SD, Standard Deviation; CV, Coefficient Variation.

TABLE 12 | Measurement uncertainty (MU).

\begin{tabular}{lr}
\hline Biotoxin & MU (\%) \\
\hline OA & 22.8 \\
DTX1 & 20.7 \\
DTX2 & 13.0 \\
PTX2 & 8.4 \\
AZA1 & 10.8 \\
AZA2 & 12.7 \\
AZA3 & 16.1 \\
YTX & 5.5 \\
1-Homo YTX & 8.4 \\
\hline
\end{tabular}

coefficient indicated a good fit for all the analytes as reported in Table 6.

The specificity was tested by analyzing 20 blank samples of different mollusc species (mussels, clams and oysters). All blank samples showed no interfering peaks in the retention time of interest for all the analytes. These blank samples were used to evaluate the limit of detection (LOD) and the limit of quantitation (LOQ) of the method, that resulted below the target concentration established by the EU harmonized SOP (2015). The LOD corresponded to $8 \mu \mathrm{g} \mathrm{kg}^{-1}$ for OA-, PTX-, DTX-, and AZA-group, and to $0.013 \mathrm{mg} \mathrm{kg}^{-1}$ for YTX-group, while the LOQ was $40 \mu \mathrm{g} \mathrm{kg}^{-1}$ for OA-, PTX-, DTX-, and AZA-group, and $0.060 \mathrm{mg} \mathrm{kg}^{-1}$ for YTX-group.

A negative sample spiked with all biotoxins for six samples at three levels in two different days considering the maximum limits and the TEF to calculate the TEQ (Toxicity

\section{REFERENCES}

Bacchiocchi, S., Siracusa, M., Ruzzi, A., Gorbi, S., Ercolessi, M., Cosentino, M. A., et al. (2015). Two-year study of lipophilic marine toxin profile in mussels of the North-central Adriatic Sea: first report of azaspiracids in Mediterranean seafood. Toxicon 108, 115-125. doi: 10.1016/j.toxicon.2015.10.002
Equivalent Quantitation) was used to calculate the recovery. In Tables 7-9 the three selected levels for validation were shown. Repeatability and reproducibility data were reported for each level in Tables 10, 11. The measurement uncertainty (MU) was calculated according to EURACHEM/CITAC Guide CG4 (2012) and shown in Table 12.

\section{CONCLUSION}

The legislation of the European Union is particularly careful about the protection of consumers from biological and chemical hazards such as the presence of contaminants in food. With regards to marine biotoxins, it requires that the sampling is carried out weekly during the period at which harvesting is allowed. The small quantities of LMB found in mussels analyzed in the present study demonstrated the good condition of the investigated marine areas as well as the security of bivalve molluscs for public health. However, when these values exceeded the maximum limits, the closure of the examined aquaculture farms should have a negative impact on the seafood industry. The method applied in this study was able to define both presence and concentrations of LMB, that must be routinely monitored in order to avoid the risk of a chronic exposure in regular consumers.

\section{AUTHOR CONTRIBUTIONS}

$\mathrm{MB}$ and GM conceived and designed the experiments; FC and FD performed the experiments; MS, PV, RT, and GS analyzed the data; NF contributed reagents, materials, analysis tools; MS and PV wrote the paper. 
non-regulated biotoxins accumulation. Mar. Environ. Res. 129, 147-155. doi: 10.1016/j.marenvres.2017.05.002

EU Harmonised Standard Operating Procedure for determination of Lipophilic marine biotoxins in molluscs by LC-MS/MS (2015). Version 5, 1-33.

European Community (2004a). Regulation (EC) No 853/2004 of the European Parliament and of the Council of 29 April 2004 laying down specific hygiene rules for food of animal origin. Off. J. Eur. Union L226, 22-82.

EURACHEM/CITAC Guide CG4 (2012). Quantifying Uncertainty in Analytical Measurement. 3rd Edn., eds S. L. R. Ellison and A. Williams (London, UK).

European Community (2004b). Regulation (EC) No 854/2004 of the European Parliament and of the Council of 29 April 2004 laying down specific rules for the organisation of official controls on products of animal origin intended for human consumption. Off. J. Eur. Union L226, 83-127.

European Community (2004c). Regulation (EC) No 882/2004 of the European Parliament and of the Council of 29 April 2004 on official controls performed to ensure the verification of compliance with feed and food law, animal health and animal welfare rules. Off. J. Eur. Union L191, 1-64.

European Community (2005). Commission Regulation (EC) No 2074/2005 of 5 December of 2005 laying down implementing measures for certain products under Regulation (EC) No 853/2004 of the European Parliament and of the Council and for the organisation of official controls under Regulation (EC) No 854/2004 of the European Parliament and of the Council and Regulation (EC) No 882/2004 of the European Parliament and of the Council, derogating from Regulation (EC) No 852/2004 of the European Parliament and of the Council and amending Regulations (EC) No 853/2004 and (EC) No 854/2004. Off. J. Eur. Union L338, 27-59.

European Community (2011). Commission Regulation (EU) No 15/2011 of 10 January of 2011 amending Regulation (EC) No 2074/2005 as regards recognised testing methods for detecting marine biotoxins in live bivalve molluscs. Off. J. Eur. Union L6, 3-6.

European Community (2013). Commission Regulation (EU) No 786/2013 of 16 August of 2013 amending Annex III to Regulation (EC) No 853/2004 of the European Parliament and of the Council as regards the permitted limits of yessotoxins in live bivalve molluscs. Off. J. Eur. Union L220:14.

European Food Safety Authority (2009). Scientific opinion of the panel on contaminants in the food chain on a request from the european commission on marine biotoxins in shellfish-summary on regulated marine biotoxins. EFSA J. 1306, 1-23.

Ferreiro, S. F., Carrera, C., Vilariño, N., Louzao, M. C., Santamarina, G., Cantalapiedra, A. G., et al. (2015). Acute cardiotoxicity evaluation of the marine biotoxins OA, DTX-1 and YTX. Toxins 7, 1030-1047. doi: 10.3390/toxins7041030

Ferreiro, S. F., Vilariño, N., Carrera, C., Louzao, M. C., Cantalapiedra, A. G., Santamarina, G., et al. (2016). Subacute cardiotoxicity of yessotoxin: in vitro and in vivo studies. Chem. Res. Toxicol. 29, 981-990. doi: 10.1021/acs.chemrestox.6b00012

Ferreiro, S. F., Vilariño, N., Carrera, C., Louzao, M. C., Santamarina, G., Cantalapiedra, A. G., et al. (2014a). In vivo arrythmogenicity of the marine biotoxin azaspiracid-2 in rats. Arch. Toxicol. 88, 425-434. doi: 10.1007/s00204-013-1115-4

Ferreiro, S. F., Vilariño, N., Louzao, M. C., Nicolau, K. C., Frederick, M. O., and Botana, L. M. (2014b). In vitro chronic effects on hERG channel caused by the marine biotoxin azaspiracid-2. Toxicon 91, 69-75. doi: 10.1016/j.toxicon.2014.09.012

Ferron, P. J., Hogeveen, K., De Sousa, G., Rahmani, R., Dubreil, E., Fessard, V., et al. (2016). Modulation of CYP3A4 activity alters the cytotoxicity of lipophilic phycotoxins in human hepatic HepaRG cells. Toxicol. In Vitro 33, 136-146. doi: 10.1016/j.tiv.2016.02.021

García, C., Oyaneder-Terrazas, J., Contreras, C., del Campo, M., Torres, R., and Contreras, H. R. (2016). Determination of the toxic variability of lipophilic biotoxins in marine bivalve and gastropod tissues treated with an industrial canning process. Food Addit. Contam. A Chem. 33, 1711-1727. doi: 10.1080/19440049.2016.1239032
Garibo, D., Campbell, K., Casanova, A., de la Iglesia, P., Fernández-Tejedor, M., Diogène, J., et al. (2014). SPR immunosensor for the detection of okadaic acid in mussels using magnetic particles as antibody carries. Sensors Actuat. B Chem. 190, 822-828. doi: 10.1016/j.snb.2013.09.037

Gerssen, A., van Olst, E. H. W., Mulder, P. P. J., and de Boer, J. (2010). In-house validation of a liquid chromatography tandem mass spectrometry method for the analysis of lipophilic marine toxins in shellfish using matrix-matched calibration. Anal. Bioanal. Chem. 397, 3079-3088. doi: 10.1007/s00216-010-3886-2

González-Romero, R., Rivera-Casas, C., Fernández-Tajes, J., Ausió, J., Méndez, J. (2012). Chromatin specialization in bivalve molluscs: a leap forward for the evaluation of okadaic acid genotoxicity in the marine environment. Comp. Biochem. Phys. C 155, 175-181. doi: 10.1016/j.cbpc.2011.09.003

Kim, J. H., Tillmann, U., Adams, N. G., Krock, B., Stutts, W. L., Deeds, J. R., et al. (2017). Identification of Azadinium species and a new azaspiracid from Azadinium poporum in Puget sound, Washington State, U.S.A. Harmful Algae 68, 152-167. doi: 10.1016/j.hal.2017.08.004

Leonardo, S., Toldrà, A., Rambla-Alegre, M., Fernández-Tejedor, M., Andree, K. B., Ferreres, L., et al. (2017). Self-assembled monolayer-based immunoassays for okadaic acid detection in seawater as monitoring tools. Mar. Environ. Res. 133, 6-14. doi: 10.1016/j.marenvres.2017.11.004

Murray, I. M. T., Rowan, N. J., McNamee, S., Campbell, K., and Fogarty, A. M. (2017). Pulsed light reduces the toxicity of the algal toxin okadaic acid to freshwater crustacean Daphnia pulex. Environ. Sci. Pollut. Res. Int. 25, 607-614. doi: 10.1007/s11356-017-0472-6

Orellana, G., Van Meulebroek, L., De Rijcke, M., Janssen, C. R., and Vanhaecke, L. (2017). High resolution mass spectrometry-based screening reveals lipophilic toxins in multiple trophic levels from the North Sea. Harmful Algae 64, 30-41. doi: 10.1016/j.hal.2017.03.005

Pistocchi, R., Guerrini, F., Pezzolesi, L., Riccardi, M., Vanucci, S., Ciminiello, P., et al. (2012). Toxin levels and profiles in microalgae from the North-Western Adriatic Sea-15 years of studies on cultured species. Mar. Drugs 10, 140-162. doi: $10.3390 / \mathrm{md} 10010140$

Schirone, M., Berti, M., Zitti, G., Ferri, N., Tofalo, R., Suzzi, G., et al. (2011). Monitoring of marine biotoxins in Mytilus galloprovincialis of Central Adriatic Sea (2006-2009). Ital. J. Food Sci. 23, 431-435.

Schirone, M., Visciano, P., Luciani, M., Ciarelli, A., Berti, M., Tofalo, R., et al. (2013). Yessotoxin determination in Mytilus galloprovincialis revealed by an in vitro functional assay. Environ. Sci. Pollut. Res. 20, 1189-1192. doi: 10.1007/s11356-012-1216-2

Trainer, V. L., Moore, L., Bill, B. D., Adams, N. G., Harrington, N., Borchert, J., et al. (2013). Diarrhetic shellfish toxins and other lipophilic toxins of human health concern in Washington State. Mar. Drugs 11, 1815-1835. doi: $10.3390 / \mathrm{md} 11061815$

Twiner, M. J., Hanagrif, J. C., Butler, S., Madhkoor, A. K., and Doucette, G. J. (2012). Induction of apoptosis pathways in several cell lines following exposure to the marine algal toxin azaspiracid. Chem. Res. Toxicol. 25, 1493-1501. doi: 10.1021/tx3001785

Visciano, P., Schirone, M., Tofalo, R., Berti, M., Luciani, M., Ferri, N., et al. (2013). Detection of yessotoxin by three different methods in Mytilus galloprovincialis of Adriatic Sea. Chemosphere 90, 1077-1082. doi: 10.1016/j.chemosphere.2012.09.012

Conflict of Interest Statement: The authors declare that the research was conducted in the absence of any commercial or financial relationships that could be construed as a potential conflict of interest.

Copyright (c) 2018 Schirone, Berti, Visciano, Chiumiento, Migliorati, Tofalo, Suzzi, Di Giacinto and Ferri. This is an open-access article distributed under the terms of the Creative Commons Attribution License (CC BY). The use, distribution or reproduction in other forums is permitted, provided the original author(s) and the copyright owner are credited and that the original publication in this journal is cited, in accordance with accepted academic practice. No use, distribution or reproduction is permitted which does not comply with these terms. 